\title{
Export-Import and Foreign Direct Investment (FDI): Indonesian Economic Study
}

\author{
Muhammad Albahi, SE, M.Si, Ak \\ Faculty of Shariah and Law, UIN Sultan Syarif Kasim, Riau, Indonesia
}

\begin{abstract}
The flow of FDI into Indonesia is expected to be able to increase productivity which will ultimately have an impact on the increase in national income in the form of the Gross Domestic Product (GDP) as well as in the form of increased exports. In other words, in order to improve his performance in international trade, investment is absolutely necessary. There is a one-way relationship between FDI and export in which the value changes FDl affect changes in the value of exports. In the short term, the increase in the value of FDl causes a decrease in the value of exports. While in the long term, the increase in value will cause a rise in the value of exports. It is caused by the nature of FDI is an investment in long-term oriented so that the benefits to the economy, including export performance can be obtained in the long term.
\end{abstract}

Keywords: Export; Import; Economy; Investment; Trade

\section{Introduction}

Indonesia's dependence on international trade as an engine of the national economy is quite large. According to Salvatore (2007), one of the economic activities that cannot be removed from international trading is capital flows, both incoming and outgoing capital from a certain country. When there is international trade activity in the form of export and import, the greater movement production from exporting countries to importing countries is due to differences in the cost of international trade.

Salvatore (2007) also states that in general, a country must not only expect on international trade, particularly exports as the sole engine driving economic growth in the present. Indonesia government should take care of his international trade which always decreases from year to year. It shows that not always benefit can be gained from trading activities, so the government must begin to think of other alternatives in order to cover the shortage. One of the efforts that the government can do is to attract foreign investors to invest in Indonesia in the form of Foreign Direct Investment (FDI).

The flow of FDI into Indonesia is expected to be able to increase productivity which will ultimately have an impact on the increase in national income in the form of the Gross Domestic Product (GDP) as well as in the form of increased exports. In other words, in order to improve his performance in international trade, investment is absolutely necessary. In addition, it is also necessary to build industrial development and infrastructure construction to boost the competitiveness of national production.

When an increase in international trade performance, the industrial sector and infrastructure development in Indonesia, will ultimately improve the competitiveness of Indonesia which is an attraction for foreign investors to invest in Indonesia.By opening the industrial sector to foreign investment can also be the main attraction for investors. FDI is expected to increase the capacity of national production, especially export. The orientation of FDI in Indonesia is still to be domestic. Governor of Bank Indonesia (2012), Nasution, stated that the inflow of foreign investment into Indonesia leads more dominant in the domestic market, not exportoriented. There is still a tendency of foreign investors to invest in industries or sectors whose output is still the domestic public consumption but it is not as export commodity.

This then leads to an imbalance between the amount of exports and imports of Indonesia that causes a deficit trade balance of Indonesia. It is consistent with the results of Indonesian Economic Report 2010, which states that the declining export performance is followed by an increase in the number of imports, particularly of capital goods and raw materials. It has an impact on the trade balance deficit. In line with the increase in imports, FDI has increased which is able to cover the current account deficit. The impact of capital inflows into the real sector generally occurs through changes in the real exchange rate of the domestic currency (exchange rate after taking into account the price levels in the countries concerned).

The real exchange rate of the domestic currency appreciating trend could adversely affect exports (weaken export competitiveness in terms of prices), but could push up the volume of imports (Bank Indonesia, 2010). Based on the above explanation, it can be concluded that there is a non-conformance links to the government's expectations of international trade (exports and imports) and FDI in Indonesia. International trade (exports and imports) and FDI are two important activity for the economy of Indonesia, which has been linked to one another. Research on the relationship between international trade and FDI also have a lot to do both abroad and in Indonesia. However, the results obtained are not always the same, some have concluded that there 
is a relationship one-way or two-way relationship and a positive relationship between international trade and FDI but there is also negatively related.

\section{Methodology}

Disclosure of trading to the total value of exports and imports to GDP has an influence on the flow of foreign investment in a certain country. According to Skipton (2007), the impact of trade openness on the level of private investment in the economy in long-term will give positive effect on economic growth indirectly. If it takes time to see the impact of trade liberalization in affecting investment behavior in the market, then there is reason to believe that there is a lag between the liberalization of trade and the level of private investment in the economy.

According to Antoni (2008), there are two aspects of the relationship between FDI by international trade, namely (1) FDI is a substitute or a complement to international trade; and (2) FDI becomes the cause of international trade or otherwise. At a first aspect, the model of Heckscher-Ohlin-Samuelson (H-O-S) stated that international trade can replace the movement amoung countries expenditure factors, one of which in the form of exports. This model explains that a State commodity trade involves the exchange between state expenditure factor indirectly. This opinion is also supported by Mundell (1957) who says that trade amoung countries and peoples movements factors expenditures (including FDI) are both a replacement. There is also other studies that refute the view above. For example, Dunning (1998) as cited by Antoni (2008), said the relationship between FDI by international trade is complementary to each other.This view is also supported by other researchers such as Lipsey, Blomstrom and Kulchycky (1988), and Pain and Wakelin (1998) as cited by Antoni (2008) resulted in the complementary relationship between exports with FDI.

The company arranged horizontally will produce a certain commodity at a location close to the possibility of the market if transportation costs are relatively high and the minimum plant size is too large. Second, scale of economies reduces the number of factories to achieve greater efficiency, but at the same time the cost of transportation and trade became obstacles to increase the number of factories.FDI can stimulate exports from the domestic sector through industry association (linkage industries) or a spill-over effect, particularly through backward linkages. This effect creates a strong demand stimulus to domestic enterprises and promote exports. Conversely, an increase in exports led to increase product.

\section{Discussion}

The analysis used in this research is the analysis of Vector Error Correction Mechanism (VECM) developed by Engle and Granger (1987) to reconcile the behavior of economic variables such as short-term/ long-term economic variable. The important concept in the VECM is a long-term balance of the time series data which is often called cointegration. In VECM, short-term relationships between variables in the system is affected by deviation from the long-term balance (Enders, 2004). VECM comes from VAR (p) by reducing the lag VAR which is equal to one in which the relevant variables are endogenous. VECM models ( $\mathrm{p}-1)$ in general is:

$$
\begin{array}{cll}
\Delta \boldsymbol{X}_{\boldsymbol{t}} & =\sum_{\boldsymbol{i = 1}}^{\boldsymbol{p - 1}} \boldsymbol{r}_{\boldsymbol{i}} \Delta \boldsymbol{X}_{\boldsymbol{t}-\mathbf{1}}+\boldsymbol{\mu}_{\mathbf{0}}+\boldsymbol{\mu}_{\mathbf{1}}+\boldsymbol{\alpha} \boldsymbol{\beta} \boldsymbol{X}_{\boldsymbol{t}-\mathbf{1}}+\boldsymbol{e}_{\boldsymbol{t}} \\
\text { Where }: \mathrm{X}_{\mathrm{t}} & =\text { vector variable observed } \\
\Delta \mathrm{X}_{\mathrm{t}} & =\mathrm{X}_{\mathrm{t}}-\mathrm{X}_{\mathrm{t}-1} \\
(\mathrm{p}-1) & =\text { lag VECM and VAR } \\
\mathrm{r}_{\mathrm{i}} & =\text { regression coefficient matrix } \\
\mu_{0} & =\text { vector intercept } \\
\mu_{1} & =\text { vector regression coefficient } \\
\alpha & =\text { loading matrix } \\
=\text { vector cointegration }
\end{array}
$$

And we may add a dummy variable monetary crisis in 1998 as an exogenous variable. In this study, the model used is the bivariate error correction so that there are two separate bivariate equation: the first is equation bivariate between exports and FDI, the second is bivariate equation between imports and FDI. As for the processing (calculation) data used, both in the descriptive analysis and time series analysis, we may use statistical software Eviews 6 and MS-Excel 2007. Before estimate the VECM models, it is required some preliminary testing that is first stationary test.

Stationary assumptions must be met before making estimates because if the data is not stationary it will cause lancing regression. So the method of inference classic cannot be applied (Gujarati (1995). Secondly, test lag optimum is used to determine the length of optimal lag that will be used in subsequent analyzes, because one of the difficulties of using VAR is the establishment of a long lag optimal . In this study, we use the criteria of 
Akaike Information criteria (AIC). Third, the Granger Causality test is used to determine the direction of the relationship variables.

Granger Causality Test results can show whether the variable studied has a relationship in one direction (one way) or two-way. Fourth, cointegration tests performs to detect the stability of long-term relationship between two or more variables. If the series of the variables studied are known to have a unit root, but the linear combination of variables that generate residual stationary, then there is a long-term relationship (cointegration) between these variables. The two series cointegrated will have a long-term stable relationship.

According to Gujarati (2003), this test is only valid if it is made on the original data which is nonstationary. Fifth, Impulse Response Forecast (IRF) is an advanced analysis that can enrich the research. In this study, IRF is used to determine the variable response of exports and imports if shocks/s /IOC and or changes in the FDI variable and vice versa. Sixth, forecast error variance decomposition which is also a follow-up analysis of the VAR / VECM.

This research is conducted using secondary data time series (time series). The variables used to achieve this goal is the value of total exports of goods (EX), the total value of imports of capital goods and raw materials/auxiliary (IM) as well as the net value of FDI respectively in USD million units. Each variable becomes real using the Wholesale Price Index (WPI) exports and imports as well as the GDP deflator.

Nominally, the development of Indonesia's exports experienced a rising trend from year to year. For activities that are vulnerable to global economic shocks, the value of Indonesian exports and imports is also decrease because of monetary crisis and the global crisis. Figure 1 shows the development of the nominal value of Indonesian exports and FDI during the study period. Based on the picture below, it appears that the significance of the decline, export performances in 2009 when the global crisis happened more significantly than during the monetary crisis in 1998/1999.

Figure 1. Export value and the value of FDI Nominal Indonesia at first quarter In 1996 till fourth quarter in 2012

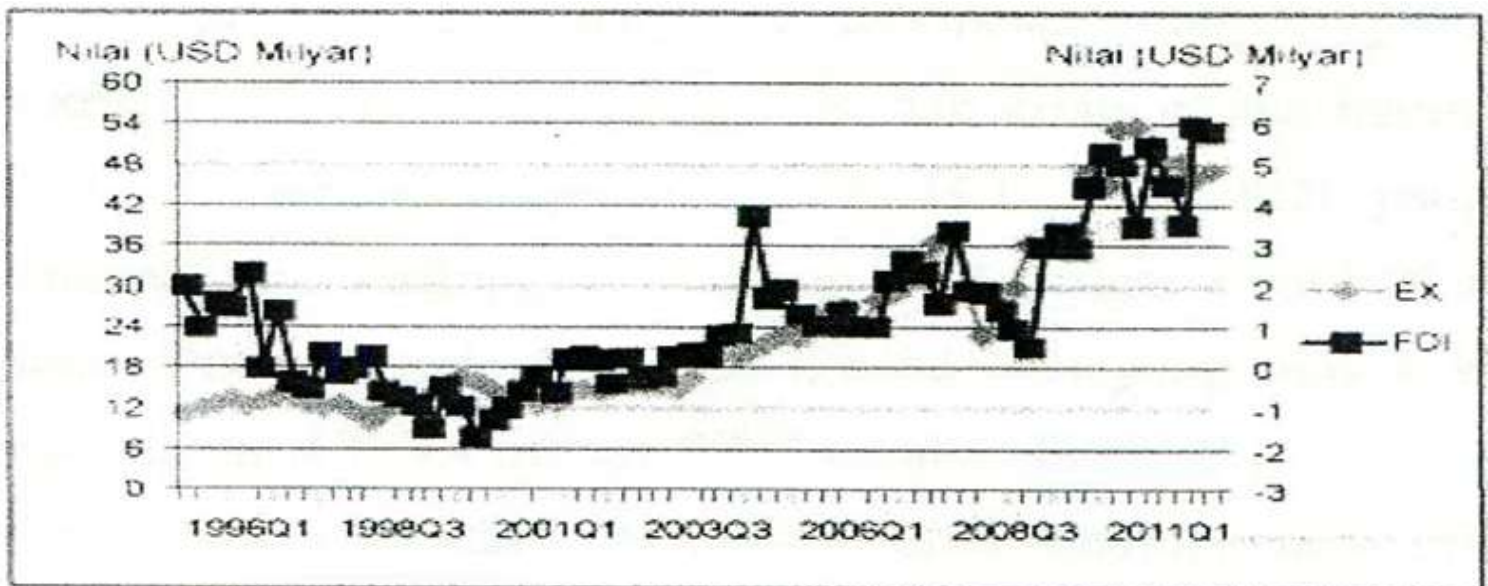

Source : BPS 2013, BI 2013

Import performance of raw materials and capital goods at figure 2 also shows that in general there is a trend similar fluctuation pattern between imports and FDI, except for the period of the financial crisis of 1998 . Similarly, the relationship between exports and FDI, it also indicates that there may be a connection or relationship between the import of raw materials and capital goods that need to be studied further using inferential analysis.

After a discussion of the general description of the relationship between exports and imports and FDI and FDI through a graph indicating the relationship between the two pairs of variables, then to further examine these relationship it is estimated through analysis of inference in the form of a method VAR / VECM. Before the estimation through VAR / VECM the initial test that must be done is stationary test. The output obtained from test performed as follows:

Table 1. The Root Test Results Summary Unit of Augmented Dickey Fuller (ADF)

\begin{tabular}{|l|l|l|l|l|}
\hline Variabel & \multicolumn{1}{l}{ Pron In Level } & explanation & Prob. In Difference 1 & Explanation \\
\hline (1) & $(\mathbf{2})$ & $(\mathbf{3})$ & $\mathbf{( 5 )}$ \\
\hline FDI & $\mathbf{0 . 1 5 6 6}$ & Not Stationery & $\mathbf{0 . 0 0 0 0}$ & Stationery \\
\hline EX & $\mathbf{0 . 0 7 7 0}$ & Not Stationery & $\mathbf{0 . 0 0 0 0}$ & Stationery \\
\hline IM & $\mathbf{0 . 2 2 0 5}$ & Not Stationery & $\mathbf{0 . 0 0 0 0}$ & Stationery \\
\hline
\end{tabular}

Source : Analysis Result 
Based on the test results of Augmented Dickey Fuller (ADF) to variables observed from the period 1996 to 2012 at First Quarter, Fourth Quarter, the result that the variable value of FDI (FDI), the value of imports (IM) and the value of exports (EX) is not stationary at the data level. Therefore, testing is done on the data at first difference. Based on the processing results, it can be obtained that these variables have been stationary at the difference the first, so it can be continued in subsequent analyzes using difference data first, the change in value of FDI (D FDI), changes in the value of imports (D IM) and the change in the value of exports ( D_EX).

Variable change is defined as the difference between the value of variables at certain Quarterly net value of the variable in the previous quarter. After stationarity test, the test is continued with optimum lag test. In this study, we uses the AIC in determining the optimum lag length. AIC value is selected as the optimum lag length which is the smallest AIC value. Tests conducted optimum lag ranging from 0 to 1 . The results of processing lag indicates that the minimum value for a pair of variables AIC exports and FDI as well as import and FDI are each contained in lag 7 and 6.The next stage is to test the Granger Causality. As long used lag is the lag 7 and 6 for each system bivariate equation between exports and FDI as well as between imports and FDI.

Table 2.Results of the Granger Causality Test

\begin{tabular}{|c|c|c|c|c|c|}
\hline Similarity & Hypothesis No & Obs & Log & F-statistics & Prob \\
\hline (1) & (2) & (3) & (4) & (5) & (6) \\
\hline \multirow[t]{2}{*}{ Ekspor dan FDI } & $\begin{array}{l}\text { D_FDI does not Granger } \\
\text { Cause D_EX }\end{array}$ & 60 & 7 & 5.30533 & 0.0002" \\
\hline & $\begin{array}{l}\text { D_EX does not Granger } \\
\text { Cause D_FDI }\end{array}$ & & & & \\
\hline \multirow[t]{2}{*}{ Impor dan FDI } & $\begin{array}{l}\text { D_FDI does not Granger } \\
\text { Cause D_IM }\end{array}$ & 61 & 6 & 6.3981 & $0.00005 "$ \\
\hline & $\begin{array}{l}\text { D_IM does not Granger } \\
\text { Cause D_FDI }\end{array}$ & & & 3.47403 & 0.0062" \\
\hline
\end{tabular}

Table 2 above shows that the pair of variables change in the value of imports (D IM) and the change in value of FDI (DFDI) has a two-way relationship indicated by the probability value of less than 5\%. It shows that the variable changes in the value of imports affecting the variable changes in the value of FDI and vice versa. Additionally result that changes in the value of FDI (D FDI) and changes in the value of exports (D_EX) has a one-way relationship that changes the value of FDI affect change in the value of exports. From the results of cointegration tests also can be concluded that there is one cointegration vector for the system of equations bivariate between exports and FDI, and there are two cointegration vector for the system of equations bivariate between imports and FDI.

Based on the test results of the Granger Causality, it can be seen that it has a strong endogenous nature (as seen from the value of most small prob) for each. Each pair of variables are variables change in value of exports and imports. Therefore, in this study used as an endogenous variable or dependent variable for each equation is the variable changes in the value of exports and changes in the value of imports of raw materials and capital goods while the variable changes in the value of FDI into exogenous or free for each bivariate equation.

After we concluded there is a long-term relationship for each pair of variables change in the value of exports and FDI as well as changes in the value of imports and FDI, then continued with the establishment of long-term equation and the short-term. Long-term equation reflects the condition of economy that is balanced without the shock of the variables in the equation system (Prasetyawati, 2012) while the short-term equation is a reflection of the real conditions teijadi on the economy coming from exogenous variables in the equation system. We obtained each pair of variables as follows:

$$
\begin{aligned}
& \mathrm{EX}_{\mathrm{t}-1}=1,75 \mathrm{FDI}_{\mathrm{t}-1}{ }^{*} \\
& \mathrm{IM}_{\mathrm{t}-1}=1,15 \mathrm{FDI}_{\mathrm{t}-1}
\end{aligned}
$$

+ An asterisk (*) indicates that the coefficient is significant at the 5\% level. Based on the equation (2), it can be interpreted that in the long term, the value of FDI has a positive and significant impact on the value of exports. When the value of FDI received by Indonesia rose by USD 1 million, it will cause a rise in the value of exports amounted to USD 1.75 million. While in equation (3) it appears that in the long term, the value of FDI also a positive effect, but not statistically significant to the value of imports.

Every increase in FDI received by Indonesia amounted to USD 1 million, it will cause a rise in the value of imports of raw materials and capital goods amounted to USD 1.15 million. Table 3 below shows that in the short term variable changes in the value of FDI in the fourth lag a negative impact and significant changes in the value of exports at this point in the short term. This means that the value of FDI in the fourth quarter ago or a year ago will reduce the value of exports in the current quarter. 
Table 3. Estimated VECM / Short Term For Couples Variable Export And Import And FDI:

\begin{tabular}{|l|l|l|l|l|l|}
\hline Export and FDI & D_EX & D_FDI & Lag & D_IM & D_FDI \\
\hline Lag & $(2)$ & $(3)$ & $(1)$ & $(2)$ & $(3)$ \\
\hline 1$)$ & O,34* & 0,57 & 1 & 0,07 & 0,33 \\
\hline 1 & 0,07 & 0,31 & 2 & $0,26 *$ & 0,36 \\
\hline 3 & 0,15 & 0,56 & 3 & $-0,27$ & 0,49 \\
\hline 4 & 0,14 & 0,85 & 4 & 0,02 & 0,11 \\
\hline 5 & 0,04 & 0,04 & 5 & 0,08 & 0,26 \\
\hline 6 & 0,02 & 0,44 & & & \\
\hline ECT & $-0,57$ & & ECT & $-0,13^{*}$ & \\
Intersep & $-74,11$ & & Intersep & 90,79 & \\
Dummy Kris. 1998 & $-4666,56$ & & Dummy Kris. 1998 & $-8729,43^{*}$ & \\
Dummy Kris. 2008 & $-3325,14 *$ & & Dummy Kris. 2008 & $-2677,70 *$ & \\
R - squared & 0,84 & R - squared & 0,71 & \\
Adj R -squared & 0,79 & Adj R -squared & 0,71 & \\
\hline
\end{tabular}

Coefficient Error Correction Term (ECT) is the speed of adjustment variable if there is disorders (shock). ECT value is negative and significant shows that changes in the value of exports are out of balance. That is, the speed of change in the value of exports to reach new equilibrium after a disturbance (shock) caused by changes in the value of FDI amounted to $53 \%$ per quarter. ECT relatively large value indicates that the time taken by the variable changes in export value to reach equilibrium faster.

Table 3 also shows that in the short term, the past behavior of imports of the previous quarter significantly influence the behavior of the present imports. This is indicated by the coefficient changes in the value of imports in the first lag valued positive and significant. This shows that the change in the value of imports of the previous quarter will likely lead to a rise in import value changes next quarter. Variable changes in the value of FDI in the short term, generally has a coefficient is positive but not statistically significant at the $5 \%$ level of testing that is on the lag first, second and fifth. ECT value of 0.13 indicates that the speed of change in the value of imports to achieve a new balance condition after a disturbance (shock) that may be caused by changes in the value of FDI is $13 \%$ per quarter. ECT value relative shows that time is needed to variable changes in the value of exports to achieve the longer.

Picture: Impluse Response Change Value of FDI on Exports

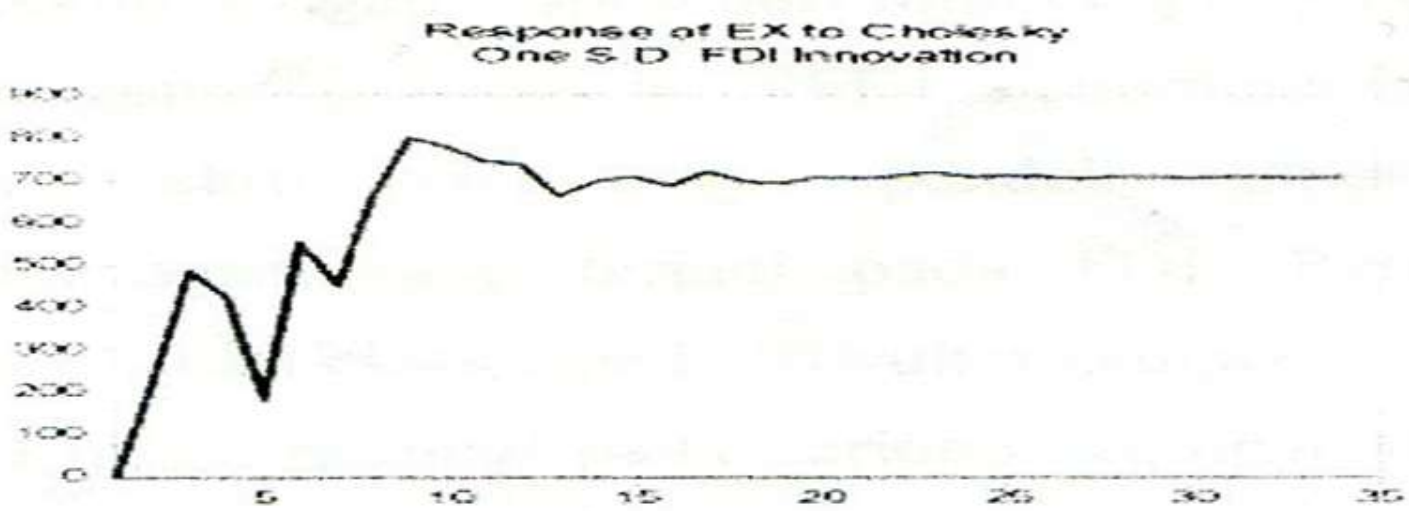

Picture: Impluse Response Change Value of FDI to Import

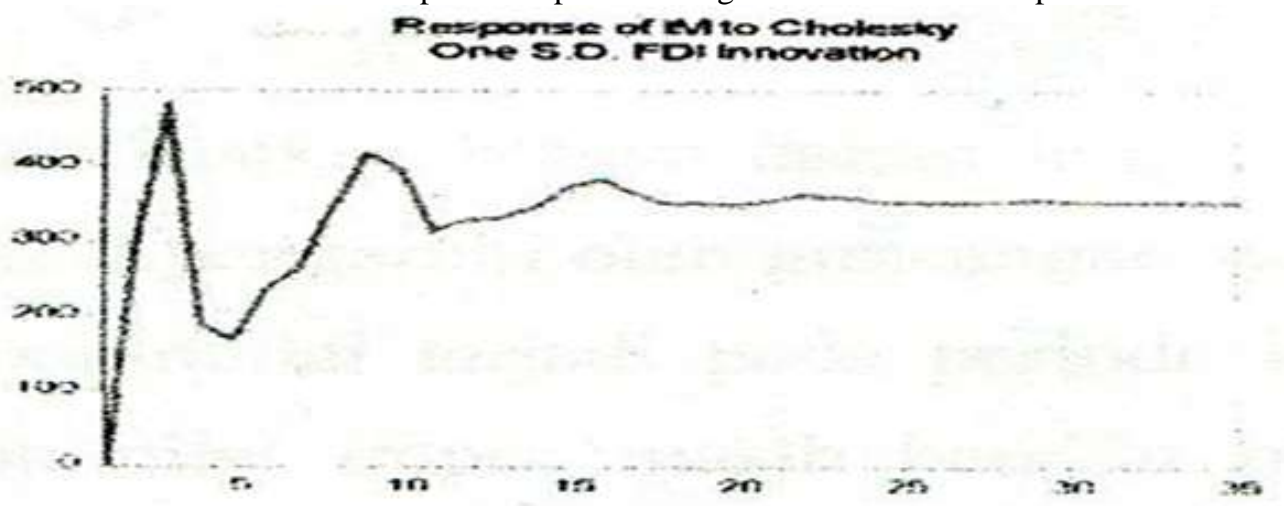


After estimating the model of VECM, we do the analysis Impulse response function as a follow-up of analysis to see the effect of the shock that occurred in FDI variable to the value of exports and imports. For bivariate equation system between exports and FDI, at first, there is no significant response from the export value because of the shock value of FDI.

This is indicated by the response of the zero export value at initial lag due to the shocks of the value of FDI. This phenomenon indicates that in a very short period of time exports tend to be influenced by the shock occuring in FDI. Positive response start is indicated by the variable value of exports in the second and third quarter.

Negative response is started to emerge during the period of the fourth and fifth. After that the response given by the value of exports to shock on the value of FDI tend to be positive and to 30 quarters next positive response which is still going great responses stable or constant. As for the system of equations bivariate imports and FDI, at first, there is no response from the import value which is significant because of the shock value of FDI. This is indicated by the response from the import value of zero at AWAI lag due to the shocks of the value of FDI. This phenomenon indicates that in a very short period of time imports tend to be influenced by the shock happening on FDI. Response to changes in the value of imports began in the second period. In the second period to the third, the response value of imports is still positive. But at the fourth and fifth periods, the response tends to be negative. Negative response to the shock value of imports FDI value change could happen if investors into Indonesia directing capital in sectors that produce goods previously imported from the investor's home country.

After that, the response given to the shock value of imports that occurred in the value of FDI tend to be positive and the next quarter to 30 positive responses still ongoing but great responses tend to be stable constant. For bivariate system of equations between the value of exports and FDI, output variance decomposition shows that the contribution of FDI to the export value large enough within the next two years, amounting to $28.24 \%$. Overall contribution of FDI to the export value tends to increase in each subsequent period. Contributions FDI to the value of exports for a period of approximately nine years to come at $68,11 \%$.

Table 4. Results Variance Decomposition Output For Each Equation

\begin{tabular}{|r|r|r|r|r|}
\hline \multirow{2}{*}{ Log } & \multicolumn{2}{|c|}{ Variance Decomposition of Ex period } & \multicolumn{2}{|c|}{ Variance Decomposition of IM period } \\
\cline { 2 - 5 } & $\mathrm{E} X$ & $\mathrm{MDI}$ & $\mathrm{F} C$ \\
\hline 1 & 100.0000 & 0.000000 & 100.0000 & $\begin{array}{r}\text { Export and FDI, } \\
\text { Import and FDI 0.000000 }\end{array}$ \\
\hline 2 & 98.31915 & 1.680849 & 96.27914 & 3.720863 \\
\hline 3 & 91.93625 & 8.063748 & 91.23208 & 8.767919 \\
\hline 4 & 87.58103 & 12.41897 & 91.85885 & 8.141152 \\
\hline 5 & 86.79761 & 12.20239 & 92.42455 & 7.575450 \\
\hline 6 & 80.37901 & 19.62099 & 91.97286 & 8.027144 \\
\hline 7 & 77.32645 & 22.67355 & 91.16336 & 8.836641 \\
\hline 8 & 71.75362 & 28.24638 & 89.58573 & 10.41427 \\
\hline 28 & 34.84681 & 65.15319 & 72.27934 & 27.72066 \\
\hline 29 & 34.33147 & 65.66853 & 72.08723 & 27.91277 \\
\hline 30 & 33.85967 & 66.14033 & 71.91088 & 28.08912 \\
\hline 31 & 33.41290 & 66.58710 & 71.74754 & 28.25246 \\
\hline 32 & 32.99585 & 67.00415 & 71.59528 & 28.40472 \\
\hline 33 & 32.60796 & 67.39204 & 71.45136 & 28.54864 \\
\hline 34 & 32.23700 & 67.76300 & 71.31297 & 28.68703 \\
\hline 35 & 31.88357 & 68.11125 & 71.17813 & 28.82187 \\
\hline
\end{tabular}

Source: Analysis Res

As for the system of equations bivariate between the value of imports and FDI, output variace decomposition shows that the contribution value of the import value fd1 large enough within the next two years, amounting to $10.41 \%$. Overall contribution to the change in value fd1 import value tends to increase in each subsequent period. Contribution of FDI to the value of imports in the period of approximately nine years to come reach $28.82 \%$. Based on the results of the Granger Causality test, there is a two-way relationship between FDI and imports. The result is in line with the results of Pacheco-Lopez (2005), which also states the presence of two-way relationship between imports and FDI. Their demand for imports from a country indicates a promising market for imported products, so investors will be interested to invest to manufacture the product in the importing country. In other words, an increase in imports will encourage FDI in importing countries.

When investors invest and make the process of production, they will import capital goods and raw materials that will increase the import bill host country. As for the pair of variables exports and FDI, the result that there is a one-way relationship, where FDI affect exports. These results are consistent with the results of research conducted Pham (2012) which states that in the long term there is a one-way relationship between exports and FDI (FDI affect exports). The annual rise in FDI will have a positive impact on the export performance of 
Indonesia. This means that the increase will push up exports FDL Indonesia through the accumulation of capital, new technologies and improvement strategies in management and marketing are usually taken or practiced by multinational companies that act as foreign investors (Pramadhani, Rakesh and Nigel, 2007).

The results of the processing output indicates that there is cointegration relationship between vafiabel for each equation bivariate and FDL export as well as import and FDI. These results are consistent with studies conducted by Pramadhani, Rakesh and Nigel (2007) who obtained results are cointegration or long-term relationship to each system of equations bivariate between exports and FDI as well as between imports and FDI in Indonesia.

Based on the results of the long-term equation estimation can be concluded that FDI in the long term be able to increase export of Indonesia. This is according to a study presented by Appleyard, Field and Cobb (2008) that one of the advantages of the FDI is increasing the productivity of goods a country which also resulted in increased exports. However, in order to contribute to export performance required a fairly long time because it is essentially FDI is a long-term investment.

Besides the result that in the long term FDI also has a positive effect on imports, but the effect is not so great. It shows that in the long term, FDI gives only a small contribution to the performance of Indonesian imports. It means that in the long term, the value of FDI in Indonesia is not so affect the value of Indonesian imports.It indicates that the performance of Indonesia import tends to be influenced by other factors such as economic growth, condition of international economy, exchange rate, etc. In addition, basically import of capital goods is goods that are durable so that the increase in imports caused by the influx of FDI will only affect the beginning of the period. But in the long term, the effect will be smaller. It is consistent with the results of Liu (1995) which states that inward of FDI does not give influence against Taiwan imports, originating from the home country (investor's home country). While based on the estimation equation of short term, it is obtained conflicting results with the results of the long-term equation. In the short term, it appears that the FDI provides a negative impact on exports.

This phenomenon shows that in a relatively short period of time, the existence of FDI can be a negative impact on Indonesia's export performance. It is because in the short term, the impact of capital inflows into the real sector generally occur through changes in the real exchange rate of the domestic currency. Higher FDI inflows into Indonesia are likely to increase demand for the rupiah which ultimately has an impact on the appreciation of the rupiah against foreign currencies.

The real exchange rate of the domestic currency appreciating trend could have a negative impact on the export performance (weaken export competitiveness in terms of prices) (Bank Indonesia, 2010). In addition, the results of the analysis also shows that the variable change in the value of exports is affected by the behavior of his past. In the short term, changes in the value of exports in the first lag effect is positively and significantly changes in the value of exports at this time.

It shows that export of the previous quarter tends to increase exports at next quarter or in other words, exports in the previous period can be a good stimulus to spur an increase export in the current period. Based on the estimation equation short term for the pair of variables imports and FDI, it can be concluded that the high import raw materials and capital goods in Indonesia is basically due to the heavy dependence on the domestic production of the imported goods and it is not solely caused by the flow of FDL into Indonesia.

\section{Conclusion}

Based on the results of the analysis, it can be concluded that there is a one-way relationship between FDI and export in which the value changes FDl affect changes in the value of exports. In the short term, the increase in the value of FDL causes a decrease in the value of exports. While in the long term, the increase in value of 25 will cause a rise in the value of exports. It is caused by the nature of FDI is an investment in longterm oriented so that the benefits to the economy, including export performance can be obtained in the long term. Meanwhile, in the short term, FDI will tend to cause the appreciation of the rupiah against the dollar and tends to weaken Indonesia's export performance.

In addition, the result that the value of imports and FDI have two-way relationship. In the short-term and long-term increase in the value of FDI tends to be a positive influence on the increase in the value of imports, but the effect is not so great. It shows that high imports of capital goods, raw materials from Indonesia is more likely to be caused by the heavy dependence on imported goods of national production.

\section{References}

[1]. Antoni, (2008). Investasi Langsung Asing (FDI) Dan Perdagangan: Bukti Empiris Di Indonesia. Jurnal Ekonomi Bisnis dan Koperasi. Vol.10 No.2, Oktober 2008. Association of South East Asian Nation [ASEAN]. (2004). Guide Bookfor Investing in ASEAN: Update 2004. Jakarta: Sekretariat ASEAN.

[2]. Appleyard, D.R., J.F.Field and S.L. Cobb. (2008). International Economics. New York: McGraw-Hill.

[3]. Bank Indonesia. (2010). Laporan Perkonomian Indonesia. Jakarta: BI.--------Bank Indonesia. (2013). Data Series Triwulan FDI 1990-2012. Jakarta: BI

[4]. Dunning, J.H. (1998). The European internal market program and inbound foreign direct investment. In: J.H Dunning (Ed),

DOI: $10.9790 / 5933-0704033744 \quad$ www.iosrjournals.org $\quad 43 \mid$ Page


Globalization, trade and foreign direct investment (pp. 49-115). Oxford:Elsevier.

[5]. Enders, W. (2004). Applied Econometric Time Series Second Edition. Hoboken: John Willey and Son, Inc.

[6]. Fontagne, L. dan M. Pajot. (2000). Foreign Trade and FDI Stocks in British, US and French Industries: Complements or Substitutes? Inward Investment, Technological Change and Growth, The Impact of Multinational Corporations on the UKEconomy (Ed. N. Pain). Palgrave Macmillan.

[7]. Gujarati, D. (1995). Basic Econometrics Third \& Fourth edition. New York: McGraw-Hill.

[8]. Haddad, M., \& Harrison, A. (1993). Are there positive spillovers from direct foreign lnvestment?Jowrwtf/ of Development Economics, 42(1), 51-74

[9]. Nailu, Z.N. (2010). Impact of Foreign Direct Investment on Trade of African Countries. International Journal of Economics and Finance Vol. 2, No. 3; August 2010

[10]. Lipsey, R.E., S.L. Blomstrom dan K.Kulchycky (1988). US and Swedish direct investment and export. R.E Baldwin (Ed.), Trade Policy Issues And Empirical Analysis (pp.259-297). Chicago: University of Chicago Press.

[11]. Liu, X. , Wang, C \& Wei, Y. 2001. Causal links between foreign direct investment and trade in China. China Economic Review, 12 (2001), 190-202.

[12]. Pacheco-Lopez, P. (2005). Foreign Direct Investment, Exports and Imports in Mexico. Mexico: Department of Economics University of Kent.

[13]. Pain, J.Y. \& Wakelin, K. (1998). Export performance and the role of foreign direct investment. Manchester School (N.SS, 66), 6288.

[14]. Pham, T.H.H. (2012). Temporal causality and the dynamics of foreign direct investment, exports and imports in Vietnam. The Journal of International Trade \& Economic Development: An International and Comparative Review. Volume 21 , Issue 1.

[15]. Pramadhani, M. , B. Rakesh Bissoondeeal and D. Nigel. (2007). FDI, Trade And Growth, A Causal Link? [Working Paper]. Birmingham (UK): Aston University.

[16]. Salvatore, D. (2007). International Economics. Prentice-Hall.

[17]. Skipton, Chuck. (2007). Trade Openness, Investment, and Long-Run Economic Growth. A working paper presented at the '07-'08 Southern Economics Association (SEA) meetings New Orleans, La. November 18-21, 2007 